\title{
THE IMPORTANCE OF MENTAL RESILIENCE AGAINST LONELINESS DURING THE COVID-19 PANDEMIC IN DIALYSIS PATIENTS
}

DOI: 10.36740/WLek202107134

\author{
Urszula Ołdakowska-Jedynak ${ }^{1}$, Maria Ryś ${ }^{2}$, Tomasz Sztajerwald ${ }^{2}$, Jolanta Malyszko' \\ 'NEPHROLOGY, DIALYSIS AND INTERNAL MEDICINE, WARSAW MEDICAL UNIVERSITY, WARSAW, POLAND \\ ${ }^{2}$ INSTITUTE OF PSYCHOLOGY, CARDINAL STEFAN WYSZYŃSKI UNIVERSITY, WARSAW, POLAND
}

\begin{abstract}
The pandemic crisis of COVID-19 has caused anxiety and depressive symptoms to increase in many people worldwide. Yet, difficult situations may not only lead to various types of disorders, fears, anxieties and feelings of loss. They can also lead to positive changes, even to development or growth after experienced trauma, to positive adaptation, to changes in self-perception, changes in interpersonal relations or philosophy of life.

Patients with chronic kidney disease, especially those on renal replacement therapy, often experience severe psychological problems such as anxiety disorders, depressive disorders, or difficulties related to coping with excessive stress.

The aim of our review is to disscus the appropriatness of mental health screening tools in patients with chronic kidney disease, including those on dialyses, during COVID-19 pandemic. Recently published studies indicate the limited available data evaluating the diagnostic accuracy of screening tools for mental status in patients with chronic kidney disease. This, it seems reasonable to stress the mental health associations with situational stress in this group of patients during the SARS-CoV-2 pandemic. It is also worth pointing out the need to research the impact of the mental disorders in this population on morbidity and mortality, taking into account other organ complications and the quality of life of patients not only during the SARS-CoV-2 pandemic. It is worth to to make every effort to reduce the severity of the anxiety and feelings of hopelessness in dialysis patients, to cope with the pandemic.
\end{abstract}

KEY WORDS: mental health, pandemic during COCID-19, end-stage renal disease, renal replacement therapy

Wiad Lek. 2021;74(7):1758-1762

\section{INTRODUCTION}

The pandemic crisis of SARS-CoV-2 (Severe Acute Respiratory Syndrome-Corona Virus-2 (SARS-CoV-2) (COVID-19) has brought enormous societal pressure worldwide. For example, in Germany as many as 30\% of respondents feared a pandemic [1], and in Poland the percentage of young adults (18-35 years old) suffering from depressed mood increased from $16.2 \%$ to $36.6 \%$ [2].

Yet, difficult situations may not only lead to various types of disorders, fears, anxieties and feelings of loss. They can also lead to positive changes, even to development or growth after experienced trauma, to positive adaptation, to changes in self-perception, changes in interpersonal relations or philosophy of life [3]. People who have experienced suffering can change their perception of reality, perceiving its different dimension. Therefore, experiencing difficult situations may lead to transforming the experienced suffering and loss into an important, positive value for a specific individual, but also into searching for more effective ways of medical or psychological interventions $[4,5]$.

COVID-19, a disease caused by a novel coronavirus, is a major global human threat and was declared a pandemic by the World Health Organization as of 11 March 2020 [6-
10]. The disease caused by this new strand of coronoavirus has high morbidity and mortality in the elderly and in comorbid populations $[7,8]$. According to the published data, older patients with underlying clinical conditions such as diabetes mellitus, hypertension, and cardiovascular disease tend to be vulnerable to COVID-19 and display more severity clinical course of the illness [9].

Chronic kidney disease (CKD) is an increasingly prevalent condition, recognized as a public health priority, affecting $10-12 \%$ of the population $[10,11]$. Chronic kidney disease and kidney end-stage renal disease (ESRD) constitute a clinical problem worlddwide. Thus, if CKD patients were to populate a separate country, its population would be the third largest in the world $[5,6]$.

CKD and uremic patients on maintenance dialysis are exposed not only to a higher comorbidity and poor quality of life, but also to a high overall mortality, mainly due to premature cardiovascular disease (CVD) and infections [9-12].

Patients with uremia receiving maintenance hemodialysis are particularly susceptible to infections because of multiple comorbidities (such as cardiovascular disease, diabetes, and cerebrovascular disease, malnutrition) and immune dysregulation compared with general population [12]. The uremia state is associated with impairment of 
lymphocyte and granulocyte function, encompassing all elements of innate and aquired immunity $[11,12]$.

Infection is the second most common cause of death in patients with ESRD [13, 14]. Dialysis patients are easily exposed to pathogens through needling, transfusion, and dialysis catheters. In addition, dialysis patients are prone to severe infection because they have uremic toxins and decreased immune function [15]. Additionaly, dialysis units accommodate many patients who are relatively mobile, so the control over the spraed of infectious diseases is more difficult than in populations at large [15].

Patients treated for chronic renal failure, especially the final stages, often experience severe psychological problems such as anxiety disorders, depressive disorders, or difficulties related to coping with excessive stress [16].

Recently published data indicate there is limited research evaluating the diagnostic accuracy of screening tools for mental status e.g. depression in patients with kidney failure $[17,18,19]$. In addition to existing studies may not be generalizable to each country and populations.

The pandemic crisis of SARS-CoV-2 has brought enormous societal pressure worldwide. We can make an effort to prepare dialysis patients, providing them with the best means with which to decrease the anxiety and feelings of hopelessness, and thus help to overcome the crisis. Patients on hemodialysis should receive education and information about COVID-19 to prevent and control infection.

\section{THE AIM}

The purpose of our study is to review theoretical basis for research in the aim to identify mental health e.g mental resilience, solitude and the feeling of loneliness screening tools appropriate for patients with kidney failure particularly during COVID-19 pandemic. We disscus the importance of mental resilience, solitude and the feeling of loneliness during the COVID-19 pandemic in a group of people with end-stage renal failure treated with hemodialysis. These patients, being in a particularly difficult health situation, had to face an additional challenge - the announced COVID-19 pandemic.

\section{REVIEW AND DISCUSSION}

\section{THE IMPORTANCE OF MENTAL RESILIENCE}

The concept of resilience explains the positive adaptation of a person despite adverse living conditions or trauma. It focuses on explaining the importance of the protective factors and mechanisms that work here [20].

Grotberg [21] describes resilience as "a universal ability that enables a person, group or community to prevent, minimize, or overcome the harmful effects of the misfortune experienced", and I. Heszen-Niejodek [22], analyzing resilience, describes it as a permanent personality trait, characterized by the ability to recover from unpleasant and difficult situations and to adapt to constantly changing living conditions.
Psychological resilience is also recognised as a characteristic of individual properties associated with adaptive flexibility resulting from an individual's ability to adjust his level of control (ego-control) to experienced situations and his own abilities [23]. It also means those qualities of a person that reflect the strength of his character, the ability to cope with stress, and the flexibility to adapt to new conditions [24]. In this perspective, mental resilience is about coping with external and internal stressors in order to cope most effectively with everyday difficulties as well as in traumatic situations [25]. The level of ego-resilience determines the flexibility of emotional, cognitive and behavioural abilities in the face of constantly changing living conditions [24].

The concept of resilience combines risk factors with resources in the process of coping with difficult situations, as well as in development and health care. For many scientists, the concept of resilience means not only a process, but also the properties of an individual to cope with any adversity in a flexible and creative way [25].

Psychological resilience is revealed when an increased level of risk occurs in a person's life, which threatens proper psychophysical development; under such conditions one can talk about good functioning of an individual [26-33].

Resilience therefore involves, on the one hand, experiencing a threat or a traumatic situation, or an increased level of risk posing a threat to the proper psychophysical development of an individual, and, on the other hand, having the skills and competences to cope with such experiences, to overcome adversity [26-29, 32, 34].

\section{SOLITUDE AND THE FEELING OF LONELINESS}

Solitude is described by researchers as an unavoidable, necessary condition stemming from human nature. Other characteristics of loneliness include ambiguity, indefiniteness and inexpressibility. It is universal and timeless. It is extremely individualised because it is experienced subjectively and very specifically. It is experienced differently by each person and reported differently by everyone [35]

Loneliness is another phenomenon. A person may feel lonely in the face of adversities, i.e. those events or life circumstances which are strongly stressful for the individual, resulting from a family or social situation (e.g. poverty, divorce of parents) or occasioned by a direct threat to life (wars, disasters, terrorist attacks) [29, 32, 37]. When defining adversity, it is very important to distinguish negative events that are a consequence of decisions made by an individual (e.g. use of psychoactive substances) from those negative events that are independent of human will and are not subject to control (e.g. illness), [26, 35,37, 38].

Among the causes of loneliness, the loosening of family and social ties and the attendant insatisfaction with needs, especially love, acceptance, contact, affiliation, reduced self-esteem and fear of rejection are often highlighted. The negative impact of working overtime, excessive involvement in technological achievements, escape into the virtual world, as well as lifestyle and culture models geared towards individual success and consumption are 
emphasised. An important cause of loneliness is also the marginalisation of religious life, or migration, emigration, excessive urbanisation and industrialisation [35, 39, 40].

One problem of loneliness in particular concerns the sick, especially those who depend on constant health care assistance.

Difficult situations cause excessive mental strain, disrupt targeted activity, jeopardise the satisfaction of needs or values important to a person, contribute to the feeling of intense emotional tension. Difficult situations, depending on individual resilience, can lead to behavioural changes, such as motor anxiety, negative emotional reactions, discouragement or a desire to give up on the chosen goals.

The feeling of loneliness is always annoying and unwanted. Loneliness limits human development and interferes with normal functioning. It is associated with a sense of hopelessness, abandonment or boredom, reduced self-esteem, alienation, an external sense of control and aggression [41], depression [42], hostility [43] or even suicidal tendencies $[44,45,46]$.

However, the experience of illness can be viewed from the perspective of a struggling man - not as a string of sufferings, but as a difficult 'school of life' with an important value.

Apart from physical diseases, the consequences of the COVID-19 pandemic on the mental health and well-being at personal and population-levels are enormous. The COVID-19 pandemic altered the routine and quality of live of large portion of the population with the relevant psychosocial impact. Imposed mass quarantine applied by nationwide lockdown programs may induce specific psychological consequences such as fear, anxiety, panic, depression, loneliness and distress [47]. Patients with endstage renal failure, often experience severe psychological problems such as anxiety disorders, depressive disorders, insomnia, or difficulties related to coping with excessive stress. Depressive disorders are the most frequent mental disorder among dialysis patients [48]. In addition the occurrence of depressive disorders is an independent factor increasing the mortality and frequency of hospitalization in this group of patients [49].

The psychological distress of patients undergoing dialysis is significantly higher and might be intensified by several reasons such as psychological reaction to stress, by uncertainty of disease progression. Regular hemodialysis treatment policy requires that every HD patient had to go to the hospitals at least 3 times a week. Besides, HD patients had more concerns of being infected and might become more stressful. In this context, it is worth analysing the problem of whether mental resilience is important in experiencing a sense of loneliness in dialysis patients. Therefore, the aim of this study is to thoroughly analyze published data on cognitive-behavioral therapy in dialysis patients.

\section{ASSESSMENT OF RESILIENCE AND LONELINESS}

\section{PSYCHOLOGICAL RESILIENCE SCALE (PRS)}

Psychological Resilience Scale was constructed by M. Ryś and co-workers. The developed items, which covered var- ious aspects of psychological resilience, were evaluated by competent judges, composed of psychologists and therapists. Factor analysis made it possible to distinguish several basic areas from which 5 scales were created in later work on the method. The reliability was calculated using Cronbach's alpha for each of the scales and was equal to: 0,697 for Attitude to difficulties and problems (PRS_1); 0,862 for Attitude to each other in difficult situations (PRS_2); 0,738 for Somatisation (PRS_3); 0,685 for Emotional sphere and relations with others (PRS_4); 0,771 for Attitude to injuries (PRS_5) [50, p. 115].

\section{ME AMONG OTHERS (MAT)- TESTING THE FEELING OF LONELINESS}

The method ME AMONG OTHERS has been developed by Maria Ryś in cooperation with psychologists and psychotherapists. The aim of this method is to determine the level of loneliness in three spheres - intellectual, emotional and functional. The initial set of items covered various aspects of relations with others and the feeling of loneliness. It was evaluated by competent judges (psychologists, therapists). Further work included only those items that were highly rated by competent judges.

The measurement is made on a Likert scale from 1 to 5 . The reliability was calculated using Cronbach's alpha for each scale and it was equal to: 0,687 for Sense of loneliness in the intellectual sphere (MAT_1); 0,863 for Sense of loneliness in the emotional sphere (MAT_2); 0,613 for Sense of loneliness in the functional sphere (MAT_3), [35]. Likert scale is a psychometric scale, the most widely applied approach to assess responses in survey research. More details concerning scaling methodology and Likert scale are discussed in literature $[35,51-53]$.

\section{CONCLUSIONS}

Summarising, the research identifying mental health screening tools appropriatness for patients with chronic kidney disease particularly during COVID-19 pandemic is very important. Recently published studies indicate the limited available data evaluating the diagnostic accuracy of screening tools for mental status in patients with chronic kidney disease. This, it seems reasonable to stress the mental health associations with situational stress in this group of patients during the SARS-CoV-2 pandemic. It is also worth pointing out the need to research the impact of the mental disorders in this population on morbidity and mortality, taking into account other organ complications and the quality of life of patients not only during the SARS-CoV-2 pandemic.

Thus, results of such studies and established method of measurements and diagnosis of mental health and disorders may allow to extend renal replacement therapy with psychological assesment and therapeutic instruments of reducing the severity of mental disorders symptoms among patients undergoing dialysis. These might have the potential of becoming new standards in the interdisciplinary care. 
The pandemic crisis of SARS-CoV-2 has brought enormous societal pressure worldwide. We should pay more attention to the patients with chronic illness, particularly with chronic kidney diseases and provide sufficient psychological support in advance.

\section{REFERENCES}

1. Gerhold L. COVID-19: Risk perception and Coping strategies. [Preprint]. Psy Ar Xiv. 2020. https://doi.org/10.31234/osf.io/xmpk4.

2. Gambin M, SękowskiM, Woźniak-Prus M, etal.Uwarunkowania objawów depresji i lęku uogólnionego u dorosłych Polaków w trakcie epidemii Covid-19. Raport z pierwszej fali badania podłużnego. Uniwersytet Warszawski, 2020. [http://psych.uw.edu.pl/2020/05/27/raport-z-ifali-badania-podluznego-uwarunkowania-objawow-depresji-i-lekuuogolnionego-u-doroslych-polakow-w-trakcie-epidemii-covid-19/].

3. Ogińska-Bulik N. Prężność jako właściwość osobowości sprzyjająca zdrowiu. In: Wrona-Polańska H (ed.). Psychologia zdrowia w służbie człowiek. Kraków: Wydawnictwo Naukowe Uniwersytetu Pedagogicznego, 2012, pp. 196-205.

4. Tedeschi RG, Calhoun LG. Posttraumatic growth: Conceptual foundations and empirical evidence. Psycholog Inq. 2004;15:1-8.

5. Tedeschi RG, Park CL, Calhoun LG. The LEA series in personality and clinical psychology. Posttraumatic growth: Positive changes in the aftermath of crisis. Mahwah, NJ, US: Lawrence Erlbaum Associates Publishers, 1998.

6. [https//www.who.int/emergencies/diseases/novel-coronavirus-2019. Accessed: 30.03.2021].

7. HuangC,WangY,LiXetal. Clinical features of patients infected with 2019 novelcoronavirusinWuhan, China. Lancet 2020;395:497-506.

8. Naicker S, Yang CW, Hwang SJ, et al. The novel coronavirus 2019 epidemic and kidneys. Kidney Int 2020; doi:10.1016/j.kint.2020.03.001.

9. Xiong F, Tang H, Liu L, et al. Clinical characteristics of and Medical Interventions for COVID-19 in hemodialysis Patients in Wuhan, China. JASN 2020; doi: 10.1681/ASN.2020030354.

10. Levin A, Tonelli M, Bonventre J, et al. Global kidney health 2017 and beyond: a roadmap for closing gaps in care, research, and policy. Lancet 2017;390:1888-1917.

11. Cobo G, Lindholm B, Stenvinkel P. Chronic inflammation in end-stage renal disease and dialysis. Nephrol Dial Transplant 2018;33:iii35-iii40; doi: $10.1093 / n d t / g f y 175$.

12. Syed-Ahmed M, Narayanan M. Immune Dysfunction and Risk of Infection in Chronic Kidney Disease. Adv Chronic Kidney Dis 2019;26:8-15.

13. Sarnak MJ, Jaber BL. Mortality caused by sepsis in patients with endstage renal disease compared with general population. Kidney Int 2000;58(4):1758-1764.

14. US Renal Data System. USRDS 2018 Annual Report:Atlas of End-Stage Renal Disease in the United States. Available at:https://www.usrds.org/ atlas03.aspx. Accessed December 30.2020.

15. Park HC, LeeYK, LeeSH, etal. Korean Society of Nephrology MERS-CoVTask Force Team: Middle East respiratory syndrome clinical practice guideline for hemodialysis facilities. Kidney Res Clin Pract 2017;36:111-116.

16. Cukor D, Coplan J, Brown C, et al. Depression and anxiety in urban hemodialysis patients. Clin J Am Soc Nephrol 2007;2:,484-90.

17. Kondo K, Antick JR, Ayers ChK, et al. Depression Screening Tools for Patients with Kidney Failure. A Systematic Review. CJASN 15:cccccc:2020. doi: 10.2215/CJN.05540420.

18. Gregg LP, Hedayati SS. Screening for Depression in People with Kidney Failure. CJASN 2020;15:ccc-ccc; doi: 10.2215/CJN.16381020.
19. Jones J. Depression: A Side Effect of CKD. CJASN 2020;15:ccc-ccc;doi: 10.2215/CJN. 16411020

20. Luthar SS, Cicchetti D, Becker B. The construct of resilience: A critical evaluation and guidelines for future work. Child Develop 2000;71(3):543-562.

21. Grotberg E. Zwiększanie odporności psychicznej, wzmacnianie sił duchowych, Warszawa: Wydawnictwo Akademickie „Żak", 2000

22. Heszen-Niejodek I (ed.). Teoretyczne i kliniczne problemy radzenia sobie ze stresem, Poznań: Stowarzyszenie Psychologia i Architektura, 2002).

23. Letzring T, Block J, Funder D. Ego-control and ego-resiliency: Generalization of self-report scales based on personality descriptions from acquaintances, clinicians and the self. J Res Person 2005;39(4): 395-422.

24. Block J, Kremen AM. IQ and ego-resiliency: Conceptual and empirical connections and separateness.J Person Soc Psychol 1996;70(2):349-361.

25. Heszen I, Sęk H. Psychologia zdrowia. Warszawa: Państwowe Wydawnictwo Naukowe, 2007.

26. Borucka A, Ostaszewski K. Czynniki i procesy resilience wśród dzieci krzywdzonych, Dziecko Krzywdzone. Teoria, Badania, Praktyka 2012;11(3):7-26.

27. Luthar SS, Cicchetti D. The construct of resilience: Implication for intervention and social policies Develop Psychopathol 2000;12:857-885.

28. Luthar SS. Resilience in development: A synthesis of research across five decades. In: Cicchetti D, Cohen DJ (eds). Developmental psychopathology: risk, disorder, and adaptation. New York: Wiley, 2006, pp. 740-795.

29. Masten A, Powell JL. A Resilience framework for research policy and practice. In: Luthar SS (ed.). Resilience and Vulnerability, New York: Cambridge University Press, 2003, pp. 1-28

30. Masten AS. Ordinary magic: Resilience processes in development. Am Psycholog. 2001;56(3):227-238.

31. Masten AS. Resilience in developing system: Progress and promise as the fourth waves rises, Develop Psychopath 2007;19:921-930.

32. Rutter M. Resilience reconsidered: Conceptual considerations, empirical findings, and policy implications. In: Shonkoff JP, Meisels SJ (eds.). Handbook of Early Childhood Intervention. New York: Cambridge University Press, 2000, pp. 651-682.

33. Vitaro $F$, Carbonneau R, Assaad JM. Les enfants de parents affectés d'une dependence. Problèmes et résilience, Québec: Presses de I'Université du Québec, 2006.

34. Borucka A, Pisarska A. Koncepcja resilience - czyli jak można pomóc dzieciom imłodzieży z grup podwyższonego ryzyka. In: Nowe wyzwania w wychowaniu i profilaktyce. Materiały konferencyjne. Warszawa: Ośrodek Rozwoju Edukacji. 2012, pp. 82-96

35. Ryś M. Poczucie osamotnienia jako symptom naszych czasow, The sense of loneliness among young pe ople as a symptom of ours times and as important educational challenge. In: Gaś ZB (ed.). Mistrzowie psychologii wobec wyzwań wspólczesności, (Psychology experts in the face of contemporary challenges). Lublin: Invocatio Press. 2020, pp. 17-52

36. Dubas E. Edukacja dorosłych w sytuacji samotności i osamotnienia. Łódź: Wydawnictwo Uniwersytetu łódzkiego, 2000.

37. Luthar SS, Zigler E. Vulnerability and Competence: A Review of Research on Resilience in Childhood. Am J Orthopsych 1991;61(1):6-22.

38. Borucka A, Ostaszewski K. Koncepcja resilience. Kluczowe pojęcia i wybrane zagadnienia. Med Wieku Rozwoj 2008;12(2):587-597.

39. Tyburski W, Domeracki P (eds). Zrozumieć samotność. Studium interdyscyplinarne. Toruń: Wydawnictwo Naukowe Uniwersytetu Mikołaja Kopernika, 2006, pp. 1-328; 350-527. 
40. Dubas E. Samotność - uniwersalny temat życia ludzkiego i wychowania. In: Tyburski W, Domeracki P (eds). Zrozumieć samotność. Studium interdyscyplinarne. Toruń: Wydawnictwo Naukowe Uniwersytetu Mikołaja Kopernika, 2006, pp. 329-349.

41. Śliwak J, Zarzycka B. Niepokój jako korelat poczucia osamotnienia u homoseksualnych mężczyzn. Rocz Psycholog 2011;14(1):177-191.

42. Szczupał B. Wybrane aspekty poczucia samotności młodzieży niepełnosprawnej, Człowiek, Niepełnosprawność, Społeczeństwo. 2005;2:47-62.

43. Lau S, Kong CK. The acceptance of lonely others: Effects of loneliness and gender of the target person and loneliness of the perceiver. J Soc Psychol 1999;139;2:229-241.

44. Bjorck JP, Thurman JW. Negative life events, patterns of positive and negative religious coping, and psychological functioning. J Sci Study Relig 2007;46(2):159-167; doi: 10.1111/j.1468-5906.2007.00348.x.

45. Edmondson D, Park CL, Chaudoir SR, Wortmann JH. Death without God: Religious struggle, death concerns, and depression in the terminally ill. Psycholog Sci 2008; 19:754-758.

46. Exline JJ. Imagery exercises and anger toward god: Two experiments. In Amy Ai (Chair), Existential Crisis--the Role of Spiritual Struggle in Adversity. Symposium conducted at the Annual Convention of the American Psychological Association, Toronto, Canada, 2009.

47. Dubey S, Biswas P, Ghosh R, et al. Psychosocial impact of COVID-19. Diabetes Metab Syndr. 2020;14:779e788)

48. Cukor D, Coplan J, Brown C, et al. Depression and anxiety in urban hemodialysis patients. Clin J Am Soc Nephrol 2007;2:484-90.

49. Lopes AA, Bragg J, Young E, et al. Depression as a predictor of mortality and hospitalization among hemodialysis patients in the United States and Europe. Kidney Int 2002;62:199-207.

50. Ryś M. Poczucie własnej wartości i odporność psychiczna osób wzrastających w różnych systemach rodzinnych, Warszawa: Wydawnictwa Naukowe UKSW, 2020.

51. Likert R. A technique for the measurement of attitudes.Arch Psychol. 1932;22:5-55.
52. Ventegodt S, Merrick J, Andersen NJ. Measurement of quality of life II. From the philosophy of life to science. Sci World J 2003;3:962-971.

53. Mircioiu C, Atkinson J. Comparison of Parametric and Non-Parametric Methods Applied to a Likert Scale. Pharmacy (Basel). 2017;10;5(2):26. doi: 10.3390/pharmacy5020026.

\section{ORCID and contributioship:}

Urszula Ołdakowska-Jedynak - 0000-0001-6356-9796 A-B,D-F Maria Ryś - 0000-0003-4287-1261 ${ }^{\text {A-B,D-F }}$

Tomasz Sztajerwald - 0000-0003-4913-7481 ${ }^{A-B, D-F}$

Jolanta Malyszko - 0000-0001-8701-8171 A,D-F

\section{Conflict of interest:}

The Authors declare no conflict of interest.

\section{CORRESPONDING AUTHOR \\ Jolanta Malyszko}

Nephrology, Dialysis and Internal Medicine

Warsaw Medical University

Banacha 1 a, 02-097, Warszawa, Poland

tel: +48225992658

e-mail:jolmal@poczta.onet.pl

Received: 10.01.2021

Accepted: 06.05.2021

A - Work concept and design, B - Data collection and analysis, C - Responsibility for statistical analysis, D-Writing the article, $\mathbf{E}$-Critical review, $\mathbf{F}$ - Final approval of the article 